\title{
EFFECTS OF SOWING DATE AND GLYCINE BETAINE APPLICATION ON YIELD COMPONENTS AND OIL YIELD IN CANOLA (Brassica napus L.)
}

\author{
Neda SAFDARI-MONFARED ${ }^{l}$, Ghorban NOOR-MOHAMMADI*l, Amir-Hossein SHIRANI-RAD ${ }^{2}$, \\ Eslam MAJIDI-HERAVAN ${ }^{I}$ \\ ${ }^{1}$ Islamic Azad University, Science and Research Branch, Department of Horticultural Science and \\ Agronomy, Tehran, IRAN. \\ ${ }^{2}$ Seed and Plant Improvement Institute (SPII), Agricultural Research, Education and Extension \\ Organization (AREEO), Karaj, IRAN. \\ *Corresponding author: noormohammadi.g@gmail.com
}

Received: 18.09.2019

\begin{abstract}
Canola (Brassica napus L.) is one of the most important oil seed crops for human consumption. Effects of sowing date and glycine betaine application on yield and oil content of canola genotypes deserve attention. The present study therefore aimed to evaluate the effect of sowing date and glycine betaine on some traits of six canola genotypes (namely Elvis, HL2012, L155, KR2, HW113 and Danob). The genotypes were sown in three sowing dates (October 7, 17, and 27), for two years (2014-2015 and 2015-2016). A factorial split-plot experiment was conducted in a complete randomized blocks design with three replications, where the sowing dates and the two levels of glycine betaine $(0$ and $0.2 \%)$ were allotted to main plots and the genotypes were allotted to subplots. The main effects of sowing date, glycine betaine and genotype were significant for almost all measured traits. The first sowing date and the application of glycine betaine had a positive effect on the all measured traits. According to the result Danob and HL2012 genotypes with high yield and oil content were more suitable for cultivation in the studied area. At the end, the determination of sowing date and choosing a suitable genotype for each region are very important to obtain high yield.
\end{abstract}

Keywords: canola, glycine betaine, oil yield, seed yield.

\section{INTRODUCTION}

Canola (Brassica napus L.) is considered to be a healthy oil for human consumption compared to other vegetable oils because of favorable combinations of the essential fatty acids in seeds (Bilgili et al., 2011; Fiebelkorn and Rahman, 2016; George et al., 2017; Rad et al., 2014). The main objective of canola breeders is to increase the seed and oil yields. These traits strongly influenced by environmental conditions and the interaction of environment and genotype (Hassanabadi et al., 2019; Marjanović-Jeromela et al., 2008). Selection of appropriate sowing date in each region is one of the important factors for achieving the maximum economic and biological yield of crops (Hossain et al., 2003). Sowing date affects the vegetative and reproductive growth period which led to change in the plant yield (Gholamian and Bayat, 2013; Turhan et al., 2011). Before the onset of cold, the plant must have sufficient growth and nutrition to provide resistance to frost (Turhan et al., 2011). Late sowing date cause to the exposure of flowering and seed maturing period with drought stress at the end of the growth season, which result in the accelerated filling and will finally result in poor quality and reduction in the yield (Morrison and Stewart, 2002; SheikhBeig-Goharrizi et al., 2016). There are different management practices to enhance the quantitative and qualitative yield of oilseed plants such as the applications of free amino acids containing compounds, bioactive oligopeptides, organic matter and mineral elements (Przybysz et al., 2014). Studies have shown that amino acids directly and indirectly affected the physiological activity of plant growth and development, and led to an increase in the yield under stress conditions (El-Aal et al., 2010; Hadi et al., 2011; Przybysz et al., 2014). Glycine betaine is an amino acid which plays a role as a cytoplasmic osmolites and protects enzymes and membranes from the effects of wastewater, and also increases the stability of cell walls against the effects of environmental stresses such as drought, salinity, cold and heat stresses (Akbari et al., 2018; SheikhBeig-Goharrizi et al., 2016). In many crops, the natural accumulation of glycine betaine is less than the amount that compensates for the harmful effects of the plant under environmental stresses (Mäkelä et al., 2019). An external application of glycine betaine may reduce the environmental stresses damages. The moderating role of glycine betaine seems to depend on several factors, such as the type of product, the 
time and rate of its application and environmental conditions (Ashraf and Foolad, 2007; Sakamoto and Murata, 2002). The application of glycine betaine improved the plant's aqueous relationships, and subsequently photosynthetic activity and hydrocarbon production increased in the plant (Xing and Rajashekar, 2001). Glycine betaine can improve growth, survival and tolerance of plants under different stress conditions (Ashraf and Foolad, 2007). Such improvements occur by the regulation of several biochemical and physiological processes, maintaining turgor pressure, enhancing the net $\mathrm{CO}_{2}$ assimilation rate and protecting functional proteins and enzymes (Qureshi et al., 2013; Agboma et al., 1997; Lopez et al., 2002). Rapeseed production in Iran is limited by a variety of stresses such as drought, salt, cold and heat. Therefore, the selection of different varieties and finding out the optimum sowing date are important for a successful production practice. The present study aimed to evaluate the effects of glycine betaine and sowing date on different varieties of rapeseed.

\section{MATERIALS AND METHODS}

\section{Exprimental conditions}

This experiment was conducted as a factorial split-plot experiment in randomized complete block design with three replications in Karaj Seed and Plant Improvement Institute $\left(35^{\circ} 49^{\prime} \mathrm{E}\right.$ and $51^{\circ} 6^{\prime} \mathrm{N}, 1321 \mathrm{~m}$ asl) during two years (2014-2015 and 2015-2016). The studied factors were included the sowing date (October 7, 17, and 27) and glycine betaine (GB was applied as 0 and $0.2 \%$ ) that were factorial in the main plots and six canola genotypes (Elvis, HL2012, L155, KR2, HW113 and Danob) were placed in subplots. The Ec of the soil equals $0.66 \mathrm{dS} \mathrm{m}^{-1}$ and the $\mathrm{pH}$ ranges from 7.2 to 7.9 (Table 1). Climate data, including temperature and precipitation for the whole year were presented in Table 2. Each plot consisted of six rows with $6 \mathrm{~m}$ long and $60 \mathrm{~cm}$ apart spaced. Seeds were sown by hand with $5 \mathrm{~cm}$ distance in rows. Two lateral rows were considered as the marginal plot. The liquid solution of glycine betaine was sprayed on the seedlings when they had 4 to 6 leaves. During the maturity stage, the following traits including plant height $(\mathrm{cm})$, stem diameter $(\mathrm{cm})$, number of branches per plant, number of silique per main stem, number of silique per shoots, number of silique per plant, number of seeds per silique, number of seeds per main silique, number of seeds per sub-silique, leaf relative water content $(\%)$, canopy temperature, 1000 -seed weight (g), seed and oil yield $\left(\mathrm{kg} \mathrm{ha}^{-1}\right)$, were measured (Table 3$)$.

The canopy temperature was measured using an infrared thermometer with a coefficient of 0.99 . Fletcher et al. (1988) method was used to measure the leaf relative water content. The youngest leaves were selected and isolated and immediately transferred to the laboratory. Five circular discs were prepared and their fresh weight was recorded. The leaf discs were transferred to an electric oven at $80^{\circ} \mathrm{C}$ and after $24 \mathrm{~h}$, the dry weight of the discs was determined with a sensitive scale. Finally, the RWC was calculated from the following equation described by Singh (1977):

$$
\text { RWC }(\%)=[(\text { FW-DW }) /(\text { TW-DW })] \times 100,
$$

Where, FW, TW, and DW are fresh, turgid, and dry weights, respectively.

Table 1. Physical and chemical characteristics of soil in the present study.

\begin{tabular}{lcccc}
\hline & \multicolumn{2}{c}{ First year } & \multicolumn{2}{c}{ Second year } \\
\cline { 2 - 5 } Specifications & $\begin{array}{c}\text { Sampling } \\
\text { depth }(\mathbf{c m})\end{array}$ & $\begin{array}{c}\text { Sampling } \\
\text { depth }(\mathbf{c m})\end{array}$ & $\begin{array}{c}\text { Sampling } \\
\text { depth }(\mathbf{c m})\end{array}$ & $\begin{array}{c}\text { Sampling } \\
\text { depth }(\mathbf{c m})\end{array}$ \\
\cline { 2 - 5 } & $\mathbf{0 - 3 0}$ & $\mathbf{3 0 - 6 0}$ & $\mathbf{0 - 3 0}$ & $\mathbf{3 0 - 6 0}$ \\
\hline Electric conductivity (dc Siemens / m) & 1.45 & 1.24 & 1.33 & 1.15 \\
$\mathrm{pH}$ & 7.9 & 7.2 & 7.8 & 7.4 \\
Percentage of neutralizing agents & 8.56 & 6.68 & 8.25 & 8.46 \\
Moisture content of saturated flower & 36 & 38 & 35 & 0.83 \\
Organic carbon (\%) & 0.91 & 0.99 & 0.08 & 0.96 \\
Total nitrogen (percent) & 0.09 & 0.07 & 14.2 & 15.3 \\
Available phosphorus (mg / kg) & 14.7 & 15.8 & 165 & 148 \\
Available potassium (mg / kg) & 197 & 155 & 29 & 27 \\
Clay percentage & 28 & 49 & 45 & 26 \\
Silt percentage & 47 & 26 & 26 \\
Sand percentage & 25 & Loam clay & Loam clay & Loamy clay \\
Soil pattern & Loam clay & & & 27 \\
\hline
\end{tabular}


Table 2. Climate data experimental from the target area.

\begin{tabular}{lllllllllll}
\hline Month & October & \multicolumn{3}{c}{ November } & \multicolumn{2}{c}{ December } & January & \multicolumn{2}{c}{ February } \\
\hline Year & $\mathbf{2 0 1 4}$ & $\mathbf{2 0 1 5}$ & $\mathbf{2 0 1 4}$ & $\mathbf{2 0 1 5}$ & $\mathbf{2 0 1 4}$ & $\mathbf{2 0 1 5}$ & $\mathbf{2 0 1 4}$ & $\mathbf{2 0 1 5}$ & $\mathbf{2 0 1 4}$ & $\mathbf{2 0 1 5}$ \\
\hline Rainfall $(\mathrm{mm})$ & 13.4 & 3.5 & 13.7 & 77.4 & 31.6 & 28.6 & 6 & 15.6 & 47.8 & 8.7 \\
Temp $\left({ }^{\circ} \mathrm{C}\right)$ & 18.1 & 19.4 & 18.2 & 10.5 & 6.3 & 4.6 & 5.2 & 5.1 & 7.3 & 4.9 \\
\hline Month & March & & April & & May & & June & & July & \\
Year & 2015 & 2016 & 2015 & 2016 & 2015 & 2016 & 2015 & 2016 & 2015 & 2016 \\
\hline Rainfall $(\mathrm{mm})$ & 21.3 & 17.8 & 45.4 & 75.5 & 2.2 & 13 & 6.6 & - & - & - \\
Temp $\left({ }^{\circ} \mathrm{C}\right)$ & 6.7 & 11.8 & 13.8 & 11.7 & 20 & 19.9 & 26.4 & 26.4 & 30.9 & 28.9 \\
\hline
\end{tabular}

\section{Data Analysis}

In order to verify the homogeneity of the error variance of the combined analysis, Bartlett's $\chi^{2}$ test was used. Since the data of the two years had homogeneous variances, the combined analysis was performed on the data which were analyzed using Statistical Analysis Software (V. 9.1; SAS Institute, Cary, NC). The mean values were compared via the LSD test (Steel and Torrie, 1980). A cluster analysis was performed in order to distinguish among the six genotypes based on the arithmetic mean method (UPGMA). The cluster analysis was performed by the SPSS software on Windows 20.0 (SPSS Inc., Chicago, IL).

\section{RESULTS AND DISCUSSION}

\section{Analysis of Variance}

Bartlett's test revealed that the data of the two years had homogeneous variances, therefore the combined analysis was performed on the data. The results of analysis of variance (ANOVA) of the measured traits showed that none of the triple and quadruple effects of the studied factors were significant, while the dual interaction of sowing date and genotype was significant for the most of the measured traits including plant height, stem diameter, number of siliques per main stem, number of siliques per branch, number of siliques per plant, number of seeds per main silique, number of seeds per silique,
1000 seed weight, and seed and oil yields (Table 3). Also, ANOVA showed that the simple effect of the three studied factors, i.e. the genotypes, the sowing dates and the two levels of GB, caused significant differences $(P<0.01$ or $P$ $<0.05)$ among the measured parameters. Rad et al. (2015) reported that all of the assessed traits including seed yield, seed oil content, seed oil yield, plant height, stem diameter, pod length, number of pods per plant, number of branches per plant, number of seeds per pod, total chlorophyll content, 1000 seeds weight, and the oleic acid content were affected by different sowing dates. Apart from the 'single seed weight', all other traits of the rapeseed were affected by the genotypes being used (Siadat and Hemayati, 2009). According to Wickens and Keppel (2004), when the interaction of factors is significant, then less attention is paid to the main effects and then the main focus will be on the interaction effects. The interaction between sowing date and year was significant for the number of siliques per main stem, number of siliques per plant, number of seeds per main silique, number of seeds per silique, and 1000-seed weight. The results indicated that the number of branches per plant had the highest coefficient of variation among the evaluated traits, indicating a high level of variation for this trait compared to the other traits among the studied genotypes. The results of the present study indicated that the canopy temperature was found as high with delay in sowing date (Table 4). 
Table 3. Analysis of variance on for the traits of canola genotypes.

\begin{tabular}{|c|c|c|c|c|c|c|c|c|c|c|c|c|c|c|c|}
\hline S.O.V & $\mathrm{df}$ & $\mathrm{PH}$ & SD & $\mathrm{CT}$ & RWC & NBP & NSMS & NSS & SNP & NSPMS & NSSS & NSPS & TSW & SY & OY \\
\hline $\mathrm{Y}$ & 1 & $* *$ & $\mathrm{~ns}$ & $* *$ & ns & $* *$ & $* *$ & ns & $* *$ & $* *$ & $* *$ & $* *$ & $* *$ & $* *$ & $* *$ \\
\hline $\mathrm{E}$ & 4 & & & & & & & & & & & & & & \\
\hline $\mathrm{S}$ & 2 & $* *$ & $* *$ & $* *$ & $* *$ & $* *$ & $* *$ & $* *$ & $* *$ & $*$ & $* *$ & $* *$ & $* *$ & $* *$ & $* *$ \\
\hline $\mathrm{Y} \times \mathrm{S}$ & 2 & ns & ns & ns & ns & ns & $* *$ & ns & $*$ & $* *$ & ns & $*$ & $* *$ & ns & ns \\
\hline GB & 1 & $* *$ & $* *$ & $* *$ & $*$ & $* *$ & $* *$ & $* *$ & $* *$ & ns & $* *$ & $* *$ & $* *$ & $* *$ & $* *$ \\
\hline $\mathrm{Y} \times \mathrm{GB}$ & 1 & ns & ns & ns & ns & ns & ns & ns & ns & ns & ns & ns & ns & ns & ns \\
\hline $\mathrm{S} \times \mathrm{GB}$ & 2 & ns & ns & ns & ns & ns & ns & ns & ns & ns & ns & ns & ns & ns & ns \\
\hline $\mathrm{Y} \times \mathrm{S} \times \mathrm{GB}$ & 2 & ns & ns & ns & ns & ns & ns & ns & ns & ns & ns & ns & ns & ns & ns \\
\hline E & 20 & & & & & & & & & & & & & & \\
\hline $\mathrm{G}$ & 5 & $* *$ & $* *$ & $* *$ & $*$ & $* *$ & $* *$ & $* *$ & $* *$ & $* *$ & $* *$ & $* *$ & $* *$ & $* *$ & $* *$ \\
\hline $\mathrm{Y} \times \mathrm{G}$ & 5 & ns & ns & ns & ns & ns & ns & ns & ns & ns & ns & ns & ns & ns & ns \\
\hline $\mathrm{S} \times \mathrm{G}$ & 10 & $* *$ & $* *$ & ns & ns & ns & $* *$ & $* *$ & $* *$ & $* *$ & ns & $* *$ & $* *$ & $* *$ & $* *$ \\
\hline $\mathrm{Y} \times \mathrm{S} \times \mathrm{G}$ & 10 & ns & ns & ns & ns & ns & ns & ns & ns & ns & ns & ns & ns & ns & ns \\
\hline $\mathrm{GB} \times \mathrm{G}$ & 5 & ns & ns & ns & ns & ns & ns & ns & ns & ns & ns & ns & ns & ns & ns \\
\hline $\mathrm{Y} \times \mathrm{GB} \times \mathrm{G}$ & 5 & ns & ns & ns & ns & ns & ns & ns & ns & ns & ns & ns & ns & ns & ns \\
\hline $\mathrm{S} \times \mathrm{GB} \times \mathrm{G}$ & 10 & ns & ns & ns & ns & ns & ns & ns & ns & ns & ns & ns & ns & ns & ns \\
\hline$\underset{\mathrm{E}}{\mathrm{Y} \times \mathrm{S} \times \mathrm{GB} \times \mathrm{G}}$ & $\begin{array}{r}10 \\
120\end{array}$ & ns & ns & ns & ns & ns & ns & ns & ns & ns & ns & ns & ns & ns & ns \\
\hline C.V (\%) & - & 4.9 & 8.7 & 3.32 & 2.46 & 18.2 & 9.6 & 8.93 & 6.78 & 7.77 & 9.43 & 6.89 & 9.51 & 11.98 & 11.92 \\
\hline
\end{tabular}

S.O.V: source of variation, df: degree of freedom, Y: year, E: error, S: sowing date, GB: Glycine-betaine, G: Genotypes, C.V: Coefficient of variation. ns, *and ** not significant and significant at P<0.05 and P<0.01, respectively. PH: Plant height, SD: Stem diameter, CT: Canopy temperature, RWC: Relative water content, NBP, Number of branches per plant, NSMS: Number of silique per main stem, NSS: Number of silique per shoots, SNP: Number of silique per plant, NSPMS: Number of seeds per main silique, NSSS: Number of seeds per sub-silique, NSPS: Number of seeds per silique, TSW: 1000-seed weight, SY: Seed yield, OY: Oil yield. 
Table 4. Main effects of planting date, glycine betaine and genotypes on measured traits of Canola.

\begin{tabular}{|c|c|c|c|c|c|c|c|}
\hline Factors & PH & SD & CT & RWC & NBP & NSMS & NSS \\
\hline \multicolumn{8}{|l|}{ Crop year } \\
\hline $2014-2015$ & $146.74 \mathrm{~b}$ & $9.80 \mathrm{a}$ & $31.49 \mathrm{a}$ & $86.46 \mathrm{a}$ & $6.74 \mathrm{~b}$ & $61.71 \mathrm{~b}$ & $99.65 \mathrm{a}$ \\
\hline $2015-2016$ & $159.60 \mathrm{a}$ & $9.84 \mathrm{a}$ & $30.69 \mathrm{~b}$ & $86.12 \mathrm{a}$ & $7.52 \mathrm{a}$ & $72.99 \mathrm{a}$ & $101.69 \mathrm{a}$ \\
\hline \multicolumn{8}{|l|}{ Planting date } \\
\hline October 7 & $182.04 \mathrm{a}$ & $13.04 \mathrm{a}$ & $29.32 \mathrm{~b}$ & $89.14 \mathrm{a}$ & $9.45 \mathrm{a}$ & $91.84 \mathrm{a}$ & $140.09 \mathrm{a}$ \\
\hline October 17 & $152.88 \mathrm{~b}$ & $9.69 \mathrm{~b}$ & $31.00 \mathrm{ab}$ & $86.01 \mathrm{ab}$ & $7.10 \mathrm{~b}$ & $67.76 \mathrm{~b}$ & $97.94 \mathrm{~b}$ \\
\hline October 27 & $125.14 \mathrm{c}$ & $6.76 \mathrm{c}$ & $32.89 \mathrm{a}$ & $83.70 \mathrm{~b}$ & $4.94 \mathrm{c}$ & $43.39 \mathrm{c}$ & $64.52 \mathrm{c}$ \\
\hline \multicolumn{8}{|l|}{$\mathrm{GB}^{\star}$} \\
\hline Control & $149.61 \mathrm{~b}$ & $9.40 \mathrm{~b}$ & $31.34 \mathrm{a}$ & $85.92 \mathrm{~b}$ & $6.83 \mathrm{~b}$ & $64.07 \mathrm{~b}$ & $95.60 \mathrm{~b}$ \\
\hline GB & $156.74 \mathrm{a}$ & $10.24 \mathrm{a}$ & $30.84 \mathrm{~b}$ & $86.67 \mathrm{a}$ & $7.43 \mathrm{a}$ & $70.63 \mathrm{a}$ & $105.74 \mathrm{a}$ \\
\hline \multicolumn{8}{|l|}{ Cultivar } \\
\hline Danob & $157.04 \mathrm{bc}$ & $10.00 \mathrm{ab}$ & $30.46 \mathrm{~b}$ & $86.34 \mathrm{bc}$ & $7.60 \mathrm{a}$ & $74.14 \mathrm{a}$ & $102.91 \mathrm{~b}$ \\
\hline Elvis & $161.42 \mathrm{ab}$ & $10.59 \mathrm{a}$ & $30.69 \mathrm{~b}$ & $86.63 \mathrm{ab}$ & $7.90 \mathrm{a}$ & $73.84 \mathrm{a}$ & $114.71 \mathrm{a}$ \\
\hline HL2012 & $151.00 \mathrm{c}$ & $9.28 \mathrm{bc}$ & $31.43 \mathrm{a}$ & $85.64 \mathrm{c}$ & $6.67 \mathrm{~b}$ & $66.21 \mathrm{~b}$ & $94.36 \mathrm{c}$ \\
\hline HW113 & $149.00 \mathrm{c}$ & $9.18 \mathrm{c}$ & $31.33 \mathrm{a}$ & $85.73 \mathrm{~cd}$ & $6.91 \mathrm{~b}$ & $66.77 \mathrm{~b}$ & $97.72 \mathrm{bc}$ \\
\hline KR2 & $150.14 \mathrm{c}$ & $9.05 \mathrm{c}$ & $31.43 \mathrm{a}$ & $84.85 \mathrm{~d}$ & $6.40 \mathrm{~b}$ & $64.20 \mathrm{~b}$ & $93.60 \mathrm{c}$ \\
\hline L155 & $164.79 \mathrm{a}$ & $10.53 \mathrm{ab}$ & $30.53 \mathrm{~b}$ & $87.46 \mathrm{a}$ & $7.85 \mathrm{a}$ & $73.52 \mathrm{a}$ & $114.89 \mathrm{a}$ \\
\hline
\end{tabular}

Table 4. Continued.

\begin{tabular}{|c|c|c|c|c|c|c|c|}
\hline Factors & SNP & NSPMS & NSSS & NSPS & TSW & SY & $\mathrm{OY}$ \\
\hline \multicolumn{8}{|l|}{ Crop year } \\
\hline 2014-2015 & $161.36 \mathrm{~b}$ & $20.41 \mathrm{~b}$ & $13.71 \mathrm{~b}$ & $17.06 \mathrm{~b}$ & $3.25 \mathrm{~b}$ & $3887 \mathrm{~b}$ & $1724 b$ \\
\hline 2015-2016 & $174.68 \mathrm{a}$ & $23.26 \mathrm{a}$ & $16.15 \mathrm{a}$ & $19.70 \mathrm{a}$ & $4.40 \mathrm{a}$ & $4630 \mathrm{a}$ & $2070 \mathrm{a}$ \\
\hline \multicolumn{8}{|l|}{ Planting date } \\
\hline October 7 & $231.93 \mathrm{a}$ & $26.07 \mathrm{a}$ & $17.56 \mathrm{a}$ & $21.82 \mathrm{a}$ & $4.76 \mathrm{a}$ & $5518 \mathrm{a}$ & $2519 \mathrm{a}$ \\
\hline October 17 & $165.70 \mathrm{~b}$ & $21.89 \mathrm{~b}$ & $15.18 \mathrm{ab}$ & $18.54 \mathrm{ab}$ & $3.87 \mathrm{ab}$ & $4283 \mathrm{~b}$ & $1897 \mathrm{~b}$ \\
\hline October 27 & $107.90 \mathrm{c}$ & $17.71 \mathrm{c}$ & $12.17 \mathrm{~b}$ & $14.94 \mathrm{~b}$ & $2.91 \mathrm{~b}$ & $2975 \mathrm{c}$ & $1276 \mathrm{c}$ \\
\hline \multicolumn{8}{|l|}{$\mathrm{GB}^{\ddagger}$} \\
\hline Control & $159.66 \mathrm{~b}$ & $21.31 \mathrm{a}$ & $14.58 \mathrm{~b}$ & $17.94 \mathrm{~b}$ & $3.71 \mathrm{~b}$ & $4098 \mathrm{~b}$ & $1818 \mathrm{~b}$ \\
\hline GB & $176.38 \mathrm{a}$ & $22.36 \mathrm{a}$ & $15.28 \mathrm{a}$ & $18.82 \mathrm{a}$ & $3.95 \mathrm{a}$ & $4419 \mathrm{a}$ & $1976 \mathrm{a}$ \\
\hline \multicolumn{8}{|l|}{ Cultivar } \\
\hline Danob & $177.04 \mathrm{~b}$ & $22.99 \mathrm{a}$ & $15.68 \mathrm{ab}$ & $19.34 \mathrm{a}$ & $4.18 \mathrm{ab}$ & $4548 \mathrm{a}$ & $2040 \mathrm{a}$ \\
\hline Elvis & $188.55 \mathrm{a}$ & $23.73 \mathrm{a}$ & $16.27 \mathrm{a}$ & $20.00 \mathrm{a}$ & $4.35 \mathrm{a}$ & $4419 \mathrm{a}$ & $1969 \mathrm{a}$ \\
\hline HL2012 & $160.58 \mathrm{c}$ & $21.62 \mathrm{~b}$ & $15.11 \mathrm{~b}$ & $18.36 \mathrm{~b}$ & $4.00 \mathrm{bc}$ & $4584 \mathrm{a}$ & $2060 \mathrm{a}$ \\
\hline HW113 & $164.49 \mathrm{c}$ & $21.25 \mathrm{~b}$ & $15.31 \mathrm{~b}$ & $18.28 \mathrm{~b}$ & $4.07 \mathrm{ab}$ & 3932 b & $1740 \mathrm{~b}$ \\
\hline KR2 & $157.80 \mathrm{c}$ & $21.64 \mathrm{~b}$ & $14.81 \mathrm{~b}$ & $18.22 \mathrm{~b}$ & $3.74 \mathrm{c}$ & $4035 \mathrm{~b}$ & $1789 \mathrm{~b}$ \\
\hline L155 & $188.41 \mathrm{a}$ & $23.46 \mathrm{a}$ & $16.00 \mathrm{a}$ & $19.73 \mathrm{a}$ & $4.20 \mathrm{ab}$ & $4034 \mathrm{~b}$ & $1786 \mathrm{~b}$ \\
\hline
\end{tabular}

The high canopy temperature can be attributed to the closure of the stomata due to the sensitivity of the stomata to water deficiency, which resulted in no transpiration and increased leaf temperature. There is a relationship between canopy temperature and photosynthesis, which the lower canopy temperature, the more photosynthesis result in more seed and oil yields (Pinter Jr et al., 1990; Kettlewell et al., 2010). Similar results were observed for the two years, three sowing date, and application of GB. However there was not relationship among the 6 genotypes. In the present study, the interaction of year and sowing date was not significant for the seed and oil yields, therefore results suggested that the sowing date of October 7 can be better than other sowing dates. Since this sowing date was earlier than the other two sowing dates, the growth and development of the plant were better and the plant was sufficiently resistant before facing the cold winter. Early sowing date resulted in more and better plant utilization of nutrients and light, which led to an increase in photosynthesis and optimum transfer of assimilates to the seeds. Early sowing dates also lead to escape of the flowering and maturity periods from the end-season drought stress and eventually result in increased seed and oil yields (Morrison and Stewart, 2002).

According to the result, application of glycine betaine significantly increased the following traits, RWC, number of branches per plant, and number of seeds per sub-silique 
compared to control. The HL2012 genotype had the highest amount of seed yield (4584 kg/ha) and seed oil yield $(2060 \mathrm{~kg} / \mathrm{ha})$. However, the lowest values of these traits were obtained in the HW113 genotype. These traits had the highest values in the first sowing date (October 7). According to table 4, delaying the sowing date reduced the average values of these traits. Siadat and Hemayati (2009) reported that delaying the sowing date caused a reduction in all yield components, especially in oilseed yield. The delay in sowing date causes the flowering period to happen in May-June when evaporation and transpiration rates peak, thereby causing the crops to suffer from water stress (Yau, 2007). During the flowering period, rapeseed is susceptible to drought stress. Nonetheless, the genotypes showed varying degrees of susceptibility. Water stress reduced the seed yield of the crop during the flowering stage (Bitarafan and Rad, 2012). The application of glycine betaine increased the amount of seed yield from 4089 to $4419(\mathrm{~kg} / \mathrm{ha})$, and increased the oil yield from 1818 to $1976(\mathrm{~kg} / \mathrm{ha})$. Glycine betaine treatments caused significant increases in seed and oil yields of canola (Dawood and Sadak, 2014). However, the interaction between sowing date and glycine betaine was not significant, while the glycine betaine appeared to be useful for the plant during the flowering period when the sowing date had been delayed. The application of glycine betaine can improve the plants tolerance to stress (Ashraf and Foolad, 2007). Glycine betaine promotes plant yield under stress conditions due to its osmoprotective effect on the photosynthetic machinery of the plant and because of its contribution to the regulation of ion homeostasis (Raza et al., 2007). It improves $\mathrm{CO}_{2}$ assimilation (Hussain et al., 2008) and assists the biosynthesis and transport of hormones (Taiz and Zeiger, 2006). There are many reports on different plants claiming that the application of glycine betaine enhanced physiological, morphological, biochemical and yield parameters (Hussain Wani et al., 2013; Giri, 2011).

The results of the mean comparison of the interaction between genotype and sowing date showed that the HL2012 and Danob genotypes had the highest mean values of seed and oil yields per hectare on the first sowing date. While, the HW113, KR2 and L155 genotypes had lower mean values not only for these two traits but also for 1000 seed weight, number of seeds per silique and number of siliques per plant (Table 5). Though in the first sowing date the highest seed and oil yields were obtained from HL2012 and Danob genotypes but in the two other sowing dates, Elvis genotype had the highest mean values for these traits.

Table 5. Interaction between sowing date and cultivar of the measured traits of canola.

\begin{tabular}{cccccccccccc}
\hline $\begin{array}{c}\text { Sowing } \\
\text { date }\end{array}$ & Cultivar & PH & SD & NSMS & NSS & SNP & NSPMS & NSPS & TSW & SY & OY \\
\hline & Danob & $192 \mathrm{a}$ & $14.2 \mathrm{a}$ & $100.2 \mathrm{a}$ & $155.4 \mathrm{a}$ & $255.7 \mathrm{a}$ & $27.3 \mathrm{ab}$ & $22.9 \mathrm{a}$ & $5.05 \mathrm{a}$ & $5878 \mathrm{a}$ & $2707 \mathrm{a}$ \\
& Elvis & $173 \mathrm{c}$ & $12.1 \mathrm{c}$ & $84.2 \mathrm{c}$ & $126.6 \mathrm{~d}$ & $211.4 \mathrm{~d}$ & $25 \mathrm{c}$ & $20.9 \mathrm{~b}$ & $4.48 \mathrm{~b}$ & $5151 \mathrm{~b}$ & $2329 \mathrm{~b}$ \\
October & HL2012 & $194 \mathrm{a}$ & $14.5 \mathrm{a}$ & $102.2 \mathrm{a}$ & $158.4 \mathrm{a}$ & $260.9 \mathrm{a}$ & $27.8 \mathrm{a}$ & $23.3 \mathrm{a}$ & $5.11 \mathrm{a}$ & $5971 \mathrm{a}$ & $2759 \mathrm{a}$ \\
7 & HW113 & $179 \mathrm{~b}$ & $12.7 \mathrm{~b}$ & $88.2 \mathrm{bc}$ & $135.5 \mathrm{bc}$ & $223 \mathrm{bc}$ & $25.6 \mathrm{c}$ & $21.4 \mathrm{~b}$ & $4.65 \mathrm{~b}$ & $5386 \mathrm{~b}$ & $2447 \mathrm{~b}$ \\
& KR2 & $182 \mathrm{~b}$ & $13 \mathrm{~b}$ & $91.2 \mathrm{~b}$ & $140.4 \mathrm{~b}$ & $232 \mathrm{~b}$ & $26 \mathrm{bc}$ & $21.7 \mathrm{~b}$ & $4.72 \mathrm{~b}$ & $5460 \mathrm{~b}$ & $2485 \mathrm{~b}$ \\
& L155 & $176 \mathrm{~b}$ & $12.4 \mathrm{~b}$ & $86.2 \mathrm{bc}$ & $131.5 \mathrm{~cd}$ & $217.9 \mathrm{~cd}$ & $25.3 \mathrm{c}$ & $21.1 \mathrm{~b}$ & $4.58 \mathrm{~b}$ & $5267 \mathrm{~b}$ & $2387 \mathrm{~b}$ \\
\hline & Danob & $159 \mathrm{~d}$ & $10.5 \mathrm{~d}$ & $73.1 \mathrm{~d}$ & $106.3 \mathrm{e}$ & $179.2 \mathrm{ef}$ & $22.9 \mathrm{~d}$ & $19.3 \mathrm{c}$ & $4.1 \mathrm{c}$ & $4573 \mathrm{c}$ & $2039 \mathrm{c}$ \\
& Elvis & $162 \mathrm{~d}$ & $10.8 \mathrm{~d}$ & $75.1 \mathrm{~d}$ & $109.4 \mathrm{e}$ & $184.6 \mathrm{e}$ & $23.4 \mathrm{~d}$ & $19.6 \mathrm{c}$ & $4.11 \mathrm{c}$ & $4687 \mathrm{c}$ & $2096 \mathrm{c}$ \\
October & HL2012 & $157 \mathrm{~d}$ & $10.2 \mathrm{~d}$ & $70.1 \mathrm{~d}$ & $102.8 \mathrm{e}$ & $173.7 \mathrm{f}$ & $22.4 \mathrm{~d}$ & $18.9 \mathrm{c}$ & $3.96 \mathrm{~cd}$ & $4510 \mathrm{c}$ & $2005 \mathrm{c}$ \\
17 & HW113 & $141 \mathrm{e}$ & $8.5 \mathrm{e}$ & $59.1 \mathrm{e}$ & $84.9 \mathrm{f}$ & $144.1 \mathrm{~g}$ & $20.1 \mathrm{e}$ & $17.2 \mathrm{~d}$ & $3.59 \mathrm{e}$ & $3868 \mathrm{~d}$ & $1695 \mathrm{~d}$ \\
& KR2 & $144 \mathrm{e}$ & $8.7 \mathrm{e}$ & $60.1 \mathrm{e}$ & $87 \mathrm{f}$ & $147.8 \mathrm{~g}$ & $20.5 \mathrm{e}$ & $17.5 \mathrm{~d}$ & $3.67 \mathrm{e}$ & $3986 \mathrm{~d}$ & $1752 \mathrm{~d}$ \\
& L155 & $127 \mathrm{e}$ & $9 \mathrm{e}$ & $63.1 \mathrm{e}$ & $89.9 \mathrm{f}$ & $153.2 \mathrm{~g}$ & $20.9 \mathrm{e}$ & $17.7 \mathrm{~d}$ & $3.07 \mathrm{de}$ & $4074 \mathrm{~d}$ & $1793 \mathrm{~d}$ \\
\hline & Danob & $127 \mathrm{f}$ & $7.1 \mathrm{f}$ & $45.1 \mathrm{f}$ & $68.7 \mathrm{~g}$ & $114.6 \mathrm{~h}$ & $18.1 \mathrm{fg}$ & $15.3 \mathrm{e}$ & $3.1 \mathrm{fg}$ & $3193 \mathrm{e}$ & $1375 \mathrm{e}$ \\
October & Elvis & $132 \mathrm{f}$ & $7.6 \mathrm{f}$ & $50.1 \mathrm{f}$ & $73.1 \mathrm{~g}$ & $123.5 \mathrm{~h}$ & $18.7 \mathrm{f}$ & $16 \mathrm{e}$ & $3.24 \mathrm{f}$ & $3420 \mathrm{e}$ & $1483 \mathrm{e}$ \\
27 & HL2012 & $129 \mathrm{f}$ & $7.4 \mathrm{f}$ & $48.1 \mathrm{f}$ & $70.3 \mathrm{~g}$ & $118.7 \mathrm{~h}$ & $18.4 \mathrm{f}$ & $15.6 \mathrm{e}$ & $3.15 \mathrm{f}$ & $3274 \mathrm{e}$ & $1416 \mathrm{e}$ \\
& HW113 & $117 \mathrm{~g}$ & $5.8 \mathrm{~g}$ & $35.8 \mathrm{~g}$ & $54.7 \mathrm{~h}$ & $89.9 \mathrm{i}$ & $16.3 \mathrm{~h}$ & $13.7 \mathrm{f}$ & $2.53 \mathrm{~h}$ & $2543 \mathrm{f}$ & $1078 \mathrm{f}$ \\
& KR2 & $118 \mathrm{~g}$ & $6 \mathrm{~g}$ & $37.9 \mathrm{~g}$ & $56.7 \mathrm{~h}$ & $93.8 \mathrm{i}$ & $16.6 \mathrm{~h}$ & $13.9 \mathrm{f}$ & $2.61 \mathrm{~h}$ & $2661 \mathrm{f}$ & $1129 \mathrm{f}$ \\
& L155 & $120 \mathrm{~g}$ & $6.2 \mathrm{~g}$ & $39.9 \mathrm{~g}$ & $59.5 \mathrm{~h}$ & $98.5 \mathrm{i}$ & $16.9 \mathrm{gh}$ & $14.2 \mathrm{f}$ & $2.72 \mathrm{gh}$ & $2761 \mathrm{f}$ & $1177 \mathrm{f}$ \\
\hline
\end{tabular}

Means within each column with different letters differ significantly at LSD 0.05. PH: Plant height, SD: Stem diameter, NSMS: Number of silique per main stem, NSS: Number of silique per shoots, SNP: Number of silique per plant, NSPMS: Number of seeds per sub-silique, NSPS: Number of seeds per silique, TSW: 1000-seed weight, SY: Seed yield, OY: Oil yield.

Delay in the sowing date has negatively affected seed and oil yields of canola due to the exposure of vegetative and reproductive stages to adverse environmental conditions. Chilling is one of the most important of these condition, which affects the plant and prevents sufficient growth and nutrition (Turhan et al., 2011; Robertson et al., 2004). Also, in delayed sowing date, the rate of emergence and development of canola seedlings decreases due to the decreased activity of the enzymes involved in the solution and the movement of the seed reserves to the meristem points, which is also due to the lack of temperatures necessary for the desired activity of the enzymes concerned. In addition, in delayed sowing date the flowering and maturation period of the plant may be faced with the end-season drought stress, which results in quick maturing, shortening the seed filling period, and preventing the optimal transfer of photosynthetic materials 
to the seeds and ultimately reducing yields(Morrison and Stewart, 2002).

\section{Cluster and PCA analyses}

The results of cluster analysis showed that the studied genotypes were classified into two main groups (Fig. 1). The HL2012, HW113 and KR2 genotypes were placed in the first group, and the second group were included Danob, Elvis and L155 genotypes. The results showed that the second group had the higher mean values of most of the measured traits compared to the first group. The Danob, Elvis and HL2012 genotypes had more seed and oil yields than the others, indicating these genotypes were more suitable for cultivation in the target area. The principal components analysis (PCA) revealed that the three first PC confirmed $97 \%$ of the total variance among genotypes (Fig. 2). About 56\% of the total variance among the genotypes was confirmed by the first PC. The genotypes were cultivated in the same condition, so the main variation among them could be due to genetic factors (Boroomand et al., 2018; Farajpour et al., 2017). The second and third components confirmed 24 and $17 \%$ of the total variance among the genotypes, respectively. The results of three plots were in a good agreement with the cluster analysis results (Fig. 2).

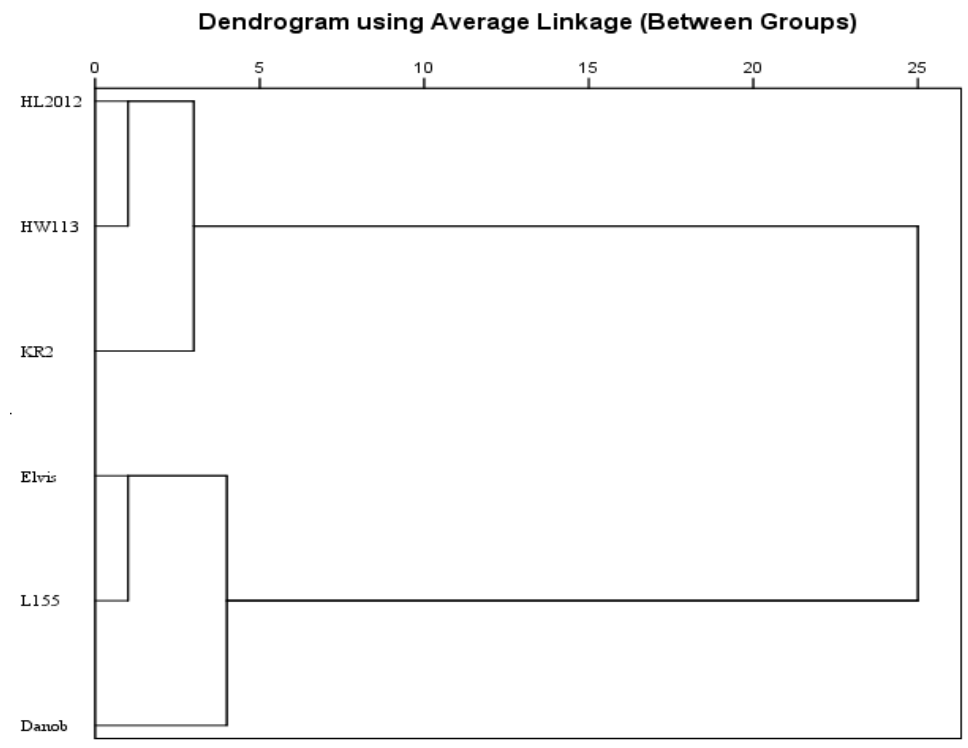

Figure 1. Dendrogram generated based on the measured traits on the six canola genotypes using UPGMA method.

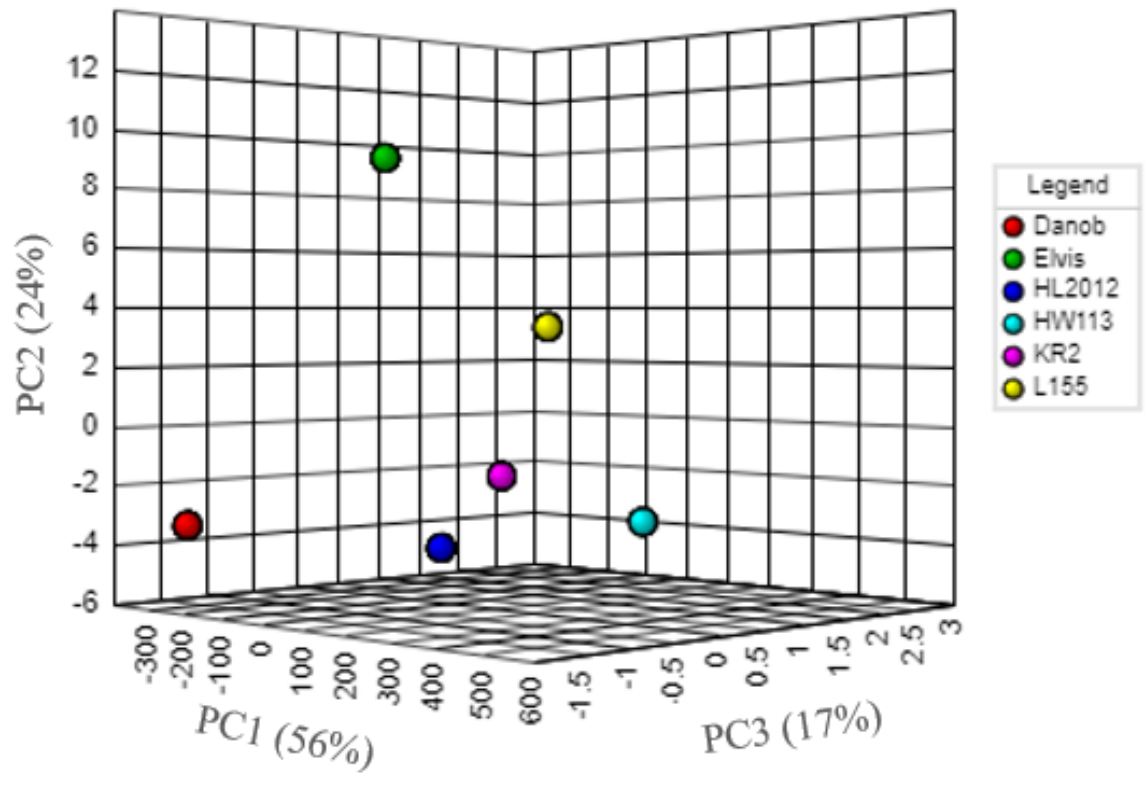

Figure 2. Three plots derived from the principal component analysis. 


\section{CONCLUSION}

The result showed that glycine betaine application had a positive effect on the seed and oil yields of canola compared to the control. Furthermore, the results demonstrated that a late sowing date is unfavorable for the plants. The results showed that three of the six genotypes were suitable for cultivation in the studied region. At the end, the determination of sowing date and choosing a suitable genotypes for each region are very important to obtain high yield.

\section{LITERATURE CITED}

Agboma, P., T. Sinclair, K. Jokinen, P. Peltonen-Sainio and E. Pehu. 1997. An evaluation of the effect of exogenous glycinebetaine on the growth and yield of soybean: timing of application, watering regimes and cultivars. Field Crops Res. 54 (1):51-64.

Akbari, M., M. Farajpour, M. Aalifar and M. Sadat Hosseini. 2018. Gamma irradiation affects the total phenol, anthocyanin and antioxidant properties in three different persian pistachio nuts. Nat. Prod. Res. 32 (3):322-326.

Ashraf, M. and M.R. Foolad. 2007. Roles of glycine betaine and proline in improving plant abiotic stress resistance. Environ. Exp. Bot. 59 (2):206-216.

Bilgili, U., E.B. Carpici, B.B. Asik and N. Celik. 2011. Root and shoot response of common vetch (Vicia sativa L.), forage pea (Pisum sativum L.) and canola (Brassica napus L.) to salt stress during early se. Turkish Journal of Field Crops. 16 (1):33-38.

Bitarafan, Z. and A.H.S. Rad. 2012. Water stress effect on spring rapeseed cultivars yield and yield components in winter planting. Int. J. Phys. Sci. 7 (19):2755-2767.

Boroomand, N., M. Sadat-Hosseini, M. Moghbeli and M. Farajpour. 2018. Phytochemical components, total phenol and mineral contents and antioxidant activity of six major medicinal plants from Rayen, Iran. Nat. Prod. Res. 32 (5):564-567.

Dawood, M.G. and M.S. Sadak. 2014. Physiological role of glycinebetaine in alleviating the deleterious effects of drought stress on canola plants (Brassica napus L.). Middle East J. Agric. Res. 3 (4):943-954.

El-Aal, F.S.A., A. Shaheen, A. Ahmed and A.R. Mahmoud. 2010. Effect of foliar application of urea and amino acids mixtures as antioxidants on growth, yield and characteristics of squash. Res. J. Agric. Biol. Sci. 6 (5):583-588.

Farajpour, M., M. Ebrahimi, A. Baghizadeh and M. Aalifar. 2017. Phytochemical and Yield Variation among Iranian Achillea millefolium Accessions. HortScience. 52 (6):827830.

Fiebelkorn, D. and M. Rahman. 2016. Development of a protocol for frost-tolerance evaluation in rapeseed/canola (Brassica napus L.). Crop J. 4 (2):147-152.

Fletcher, R., M. Santakumari and D. Murr. 1988. Imposition of water stress in wheat seedlings improves the efficacy of uniconazole-induced thermal resistance. Physiol. Plant. 74 (2):360-364.

George, N., L. Levers, S. Thompson, J. Hollingsworth and S. Kaffka. 2017. Modeling identifies optimal fall planting times and irrigation requirements for canola and camelina at locations across California. Calif. Agric. 71 (4):214-220.

Gholamian, A. and M. Bayat. 2013. Study of Delay Cultivation on Seed Yield and Seed Quality of Canola (Brassica napus L.) Genotypes. Agrotechnol. 2 (108):2.

Giri, J. 2011. Glycinebetaine and abiotic stress tolerance in plants. Plant Signal Behav. 6 (11):1746-1751.
Hadi, M.R.H.S., M.T. Darz, Z. Gh and G. Riazi. 2011. Effects of vermicompost and amino acids on the flower yield and essential oil production from Matricaria chamomile L. J. Med. Plants Res. 5 (23):5611-5617.

Hassanabadi, M., M. Ebrahimi, M. Farajpour and A. Dejahang. 2019. Variation in essential oil components among Iranian Ferula assa-foetida L. accessions. Ind. Crops. Prod. 140:11598.

Hossain, I., F.M. Epplin and E.G. Krenzer. 2003. Planting date influence on dual-purpose winter wheat forage yield, grain yield, and test weight. Agron.J. 95 (5):1179-1188.

Hussain, M., M. Farooq, K. Jabran, H. Rehman and M. Akram. 2008. Exogenous glycinebetaine application improves yield under water-limited conditions in hybrid sunflower. Arch. Agron. Soil. Sci. 54 (5):557-567.

Hussain Wani, S., N. Brajendra Singh, A. Haribhushan and J. Iqbal Mir. 2013. Compatible solute engineering in plants for abiotic stress tolerance-role of glycine betaine. Curr. Genom. 14 (3):157-165.

Kettlewell, P.S., W.L. Heath and I.M. Haigh. 2010. Yield enhancement of droughted wheat by film antitranspirant application: rationale and evidence. Agric. Sci. 1 (03):143.

Lopez, C., H. Takahashi and S. Yamazaki. 2002. Plant-water relations of kidney bean plants treated with $\mathrm{NaCl}$ and foliarly applied glycinebetaine. J.Agron.Crop Sci. 188 (2):73-80.

Mäkelä, P.S., K. Jokinen and K. Himanen. 2019. "Roles of Endogenous Glycinebetaine in Plant Abiotic Stress Responses." In Osmoprotectant-Mediated Abiotic Stress Tolerance in Plants, 153-173. Springer.

Marjanović-Jeromela, A., R. Marinković, A. Mijić, Z. Zdunić, S. Ivanovska and M. Jankulovska. 2008. Correlation and path analysis of quantitative traits in winter rapeseed (Brassica napus L.). Agric. conspec. sci. 73 (1):13-18.

Morrison, M.J. and D.W. Stewart. 2002. Heat stress during flowering in summer Brassica. Crop Sci. 42 (3):797-803.

Pinter Jr, P., G. Zipoli, R. Reginato, R. Jackson, S. Idso and J. Hohman. 1990. Canopy temperature as an indicator of differential water use and yield performance among wheat cultivars. Agric. Water Manag. 18 (1):35-48.

Przybysz, A., H. Gawrońska and J. Gajc-Wolska. 2014. Biological mode of action of a nitrophenolates-based biostimulant: case study. Front. Plant Sci. 5:713.

Qureshi, K.M., S. Chughtai, U.S. Qureshi and N.A. Abbasi. 2013. Impact of exogenous application of salt and growth regulators on growth and yield of strawberry. Pak. J. Bot. 45 (4):1179-1185.

Rad, A.H.S., Z. Bitarafan, F. Rahmani, T. Taherkhani, A.M. Aghdam and S. Nasresfahani. 2014. Effects of planting date on spring rapeseed (Brassica napus L.) cultivars under different irrigation regimes. Turkish Journal of Field Crops. 19 (2):153-157.

Raza, S.H., H.R. Athar, M. Ashraf and A. Hameed. 2007. Glycinebetaine-induced modulation of antioxidant enzymes activities and ion accumulation in two wheat cultivars differing in salt tolerance. Environ. Exp. Bot. 60 (3):368376.

Robertson, M., J. Holland and R. Bambach. 2004. Response of canola and Indian mustard to sowing date in the grain belt of north-eastern Australia. Aust. J. Exp. Agric. 44 (1):43-52.

Sakamoto, A. and N. Murata. 2002. The role of glycine betaine in the protection of plants from stress: clues from transgenic plants. Plant Cell Environ. 25 (2):163-171.

SheikhBeig-Goharrizi, M.-A., A. Dejahang, M. Tohidfar, A. Izadi-Darbandi, N.J. Carrillo, M.-R. Hajirezaei and K. Vahdati. 2016. Agrobacterium mediated transformation of somatic embryos of Persian walnut using fld gene for osmotic stress tolerance. J. Agr. Sci. Tech-Iran. 18:423-435. 
Siadat, S. and S. Hemayati. 2009. Effect of sowing date on yield and yield components of three oilseed rape varieties. Plant Ecophysiol. 1:31-35.

Singh, A. 1977. Practical Plant Physiology. New Delshi: Kalyari Publishers.

Steel, R.G. and J.H. Torrie. 1980. Principles and Procedures of Statistics, A Biometrical Approach. 2 ed. New York: McGraw-Hill Publ. Company.

Taiz, L. and E. Zeiger. 2006. Stress physiology. 4 ed, Plant Physiol. Sunderland: Sinauer Associates, Inc.

Turhan, H., M.K. Gül, C.Ö. Egesel and F. Kahriman. 2011. Effect of sowing time on grain yield, oil content, and fatty acids in rapeseed (Brassica napus subsp. oleifera). Turk. J. Agric. For. 35 (3):225-234.

Wickens, T.D. and G. Keppel. 2004. Design and Analysis: A Researcher's Handbook. New Jersey: Pearson Prentice-Hall.
Xing, W. and C. Rajashekar. 2001. Glycine betaine involvement in freezing tolerance and water stress in Arabidopsis thaliana. Environ. Exp. Bot. 46 (1):21-28.

Yau, S. 2007. Winter versus spring sowing of rain-fed safflower in a semi-arid, high-elevation Mediterranean environment. Eur. J. Agron. 26 (3):249-256. 